\title{
和歌山県田辺市本宮町川湯温泉周辺の露頭の赤外線画像
}

\section{Infrared images of outcrops around the Kawayu hot springs, Hongucho, Tanabe City, Wakayama Prefecture}

$$
\text { 島田耕史 }{ }^{*} \cdot \text { 後藤 翠* } \cdot \text { 丹羽正和 }{ }^{*} \cdot \text { 下茂道人 }{ }^{* *}
$$

\section{Koji Shimada , Akira Goto*, Masakazu Niwa* and Michito Shimo ${ }^{* *}$}

2021 年 5 月 7 日受付.

2021 年 8 月 5 日受理.

日本原子力研究開発機構東濃地科学センター

Tono Geoscience Center, Japan Atomic Energy Agency, 959-

31, Jorinji, Izumi-cho, Toki, Gifu 509-5102, Japan

赤外線画像は, 簡単な撮影方法で温度分布を可視化するため, 地下からの高温流体 (液体・気体) の滲出地点の迅速把握に有用 である．気体の滲出は，それにより加熱された固体からの赤外 線として検出される. 複数地点から温泉が湧出する川湯(かわ ゆ)温泉の露頭 (Figs. 1, 2) における赤外線画像を用いた調査の 例を紹介する. 非火山地帯における高温流体滲出機構の解明の ための基礎として，本露頭周辺では周囲より高温の割れ目の分 布調査を進めている. 赤外線画像撮影の結果, 川岸や川底から の温泉湧出による露頭や水面の温度上昇(Fig. 3), 高濃度メ夕 ンを含む気体と温泉が滲出する割れ目周辺の岩石の温度上昇 (Fig. 4) が可視化された. この割れ目は冬季の仙人風呂の土手 造成で埋没し，翌春には温度上昇を確認できなくなった (Fig. 5)。本報告は資源エネルギー庁委託事業（地質環境長期安定性 評価技術高度化開発)の成果の一部である.

Keywords: Infrared image, deep-seated fluid, flow path
** 深田地質研究所

Fukada Geological Institute, 2-13-12, Hon-Komagome, Bunkyo-ku, Tokyo 113-0021, Japan

Corresponding Author: K. Shimada, shimada.koji@jaea.go.jp

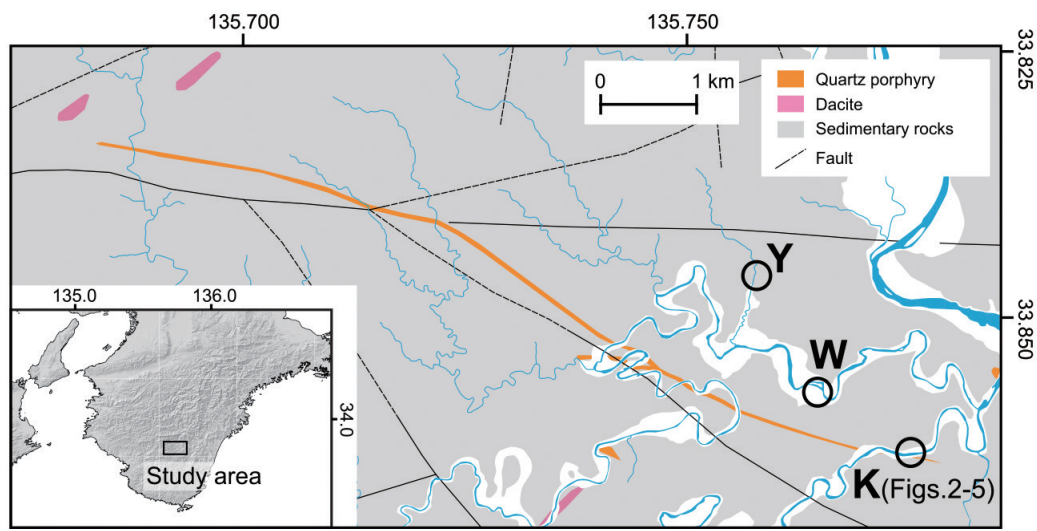

Fig. 1. Geological map of the Kawayu hot springs and surroundings. The distribution of the longest quartz porphyry body is partly modified based on our research from the Seamless Digital Geological Map of Japan 1:200,000 (Geological Survey of Japan, AIST, ed., 2015). Abbreviations: K, Kawayu hot springs; Y, Yunomine hot springs; and W, Watarase hot springs.

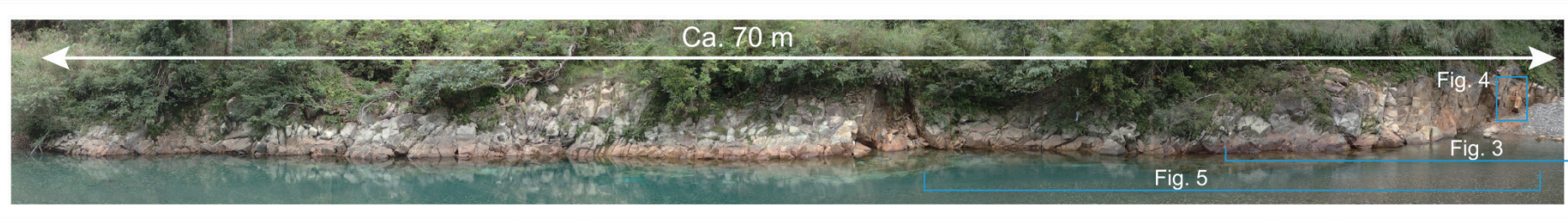

Fig. 2. Quartz porphyry outcrop at the Kawayu hot springs. The locations of Figs 3 to 5 are shown.
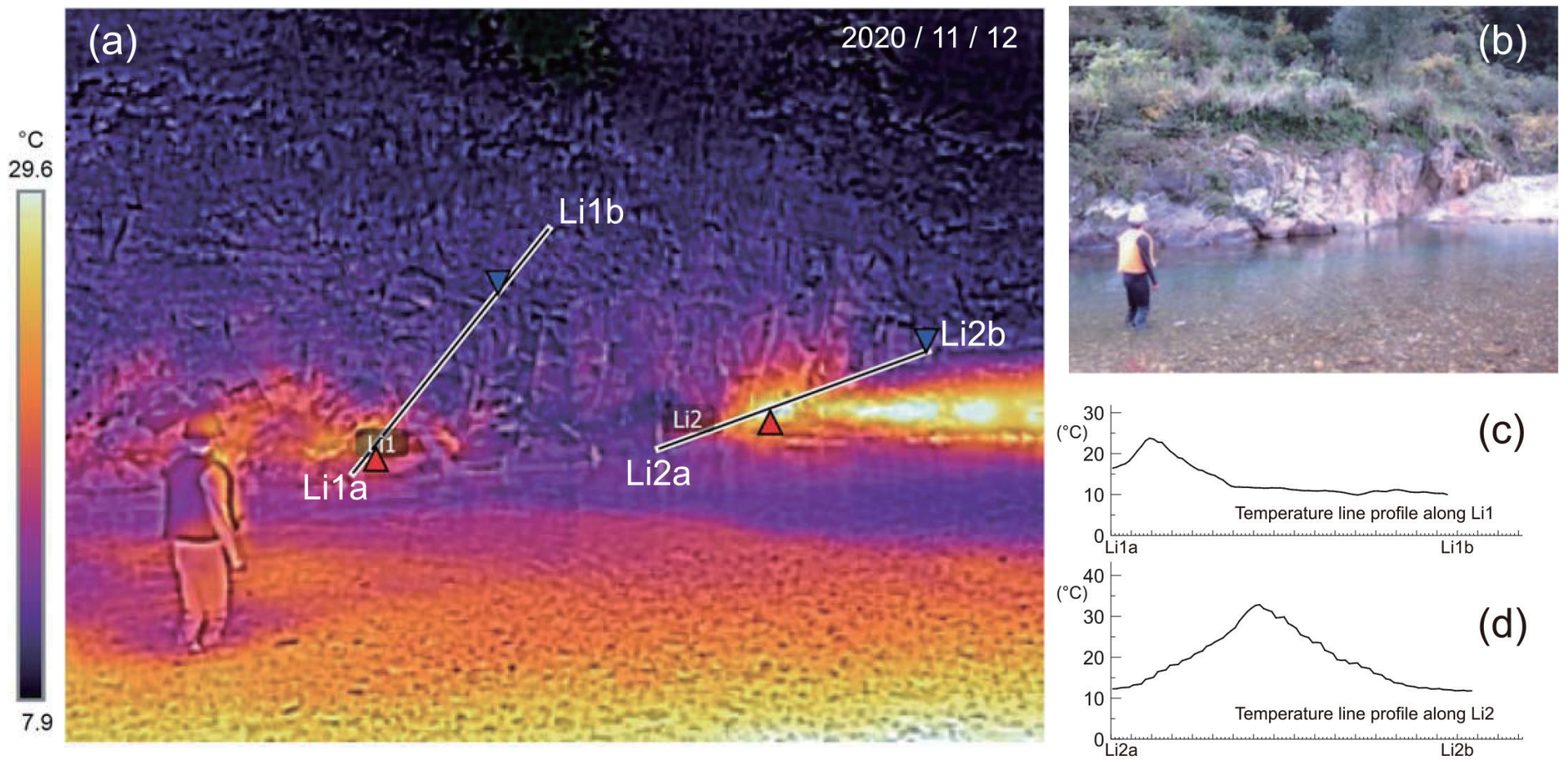

Fig. 3. (a) FLIR C5 infrared image of the quartz porphyry (Fig. 2) showing the location of temperature scan lines Li1 and Li2. Red and blue triangles are the points of maximum and minimum temperature, respectively, along the scan lines (using FLIR Tools). (b) Visible light image of (a). (c) Temperature line profile along Li1. (d) Temperature line profile along Li2. 


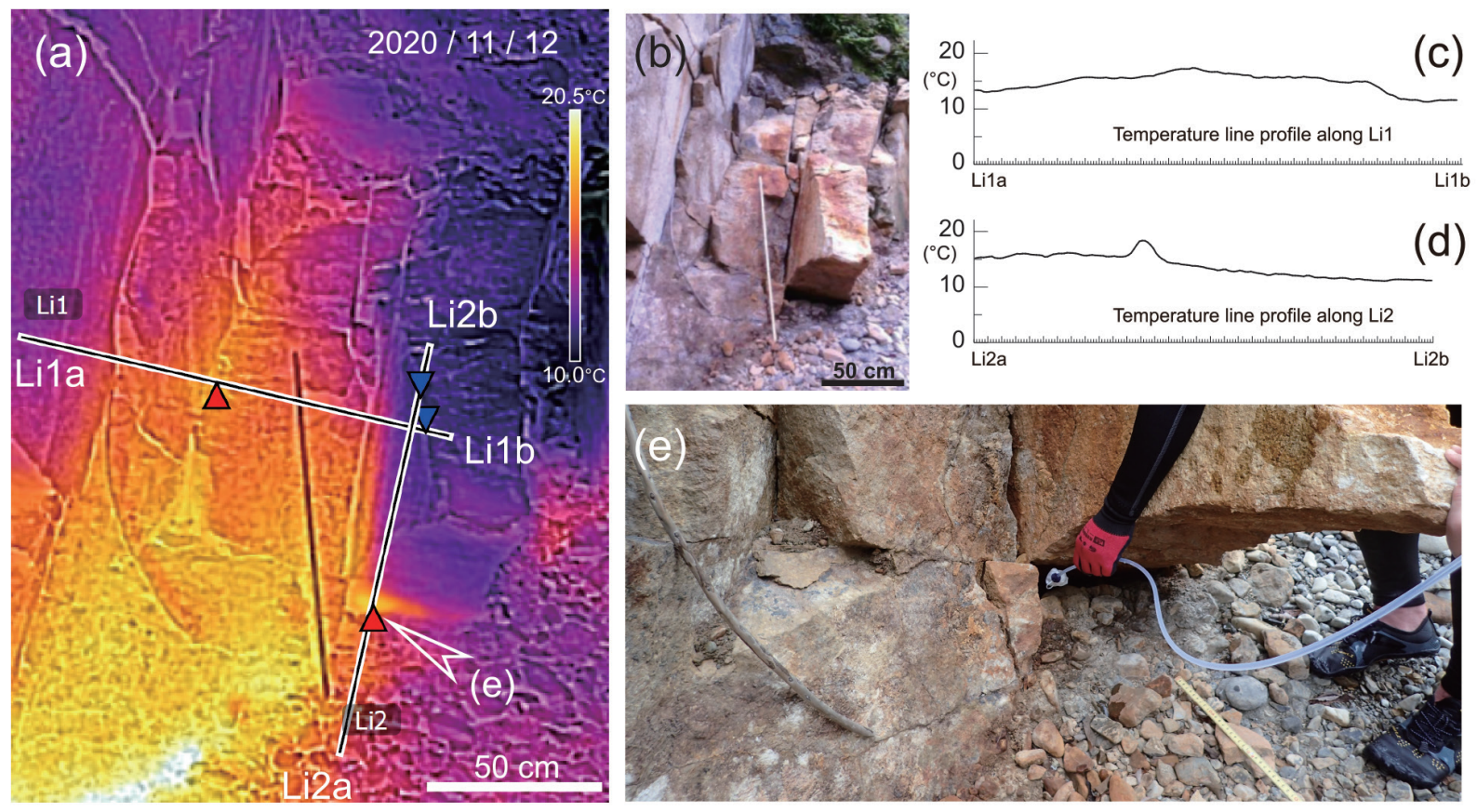

Fig. 4. (a) FLIR C5 infrared image of the quartz porphyry (Fig. 2) showing the location of temperature scan lines Li1 and Li2; the red and blue triangles are described in Fig. 3(a). (b) Visible light image of Fig. 4(a). (c) Temperature line profile along Li1. (d) Temperature line profile along Li2 (d). (e) A high concentration of methane (100-680 ppm) was detected using a Picarro GasScouter ${ }^{\mathrm{TM}}$ G4301 device. Warm gas is seeping out of an open crack, but the infrared image (a) does not show the gas temperature; it shows the warm surface temperature of the rock, probably resulting from heat conduction.

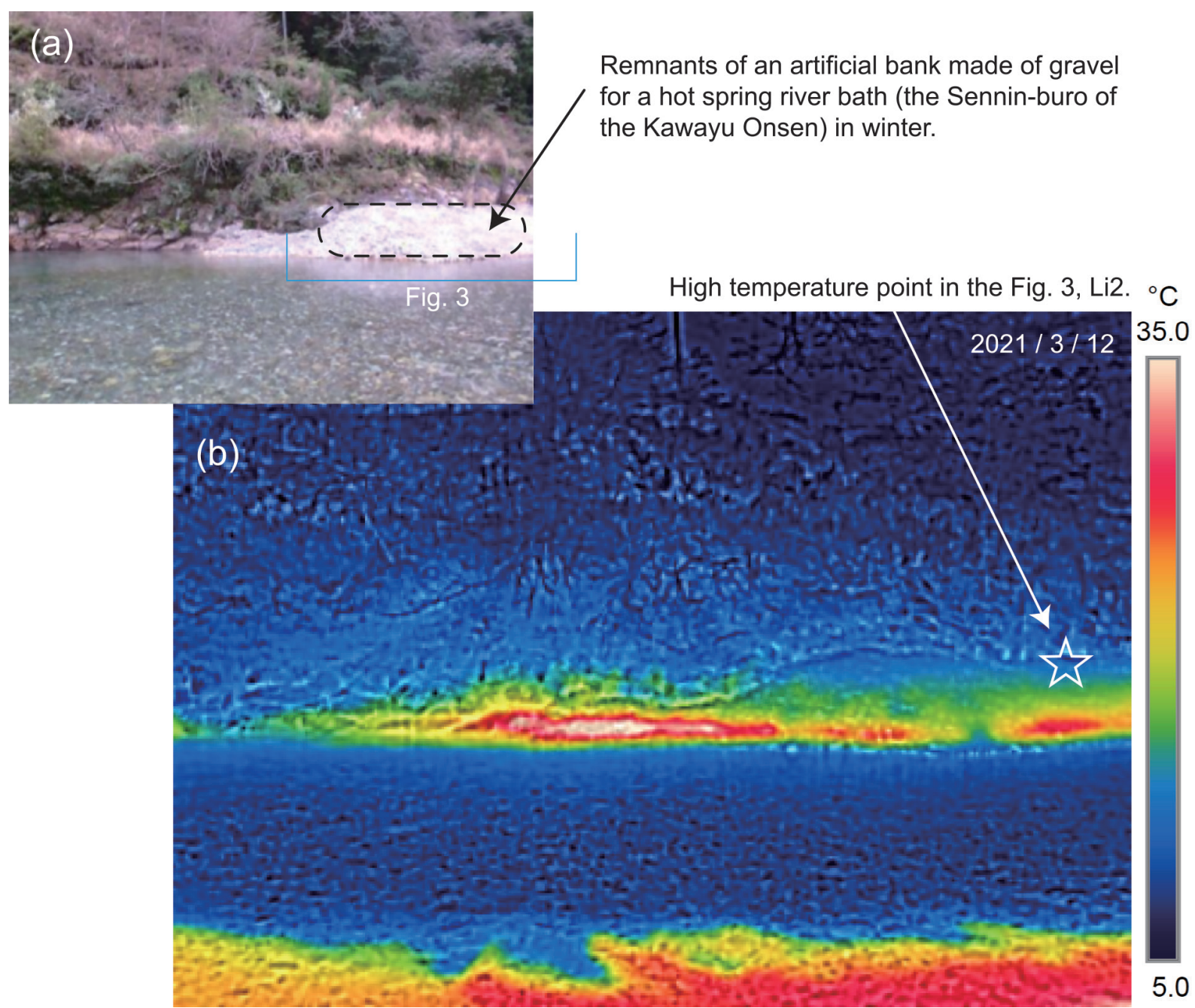

Fig. 5. Visible light (a) and infrared (b) images of the Kawayu hot springs (Fig. 2) after the artificial bank was demolished in the spring. The high temperature point measured in the late autumn (Fig. 3) has been covered by part of an artificial gravel bank, with no sign of high temperature. Although the change in the thermal environment is notable, what is causing the change in the water or gas paths is uncertain. Kawayu Onsen: Kawayu hot springs in Japanese.

文 献

Geological Survey of Japan, AIST, ed., 2015, Seamless Digital Geological Map of Japan 1: 200,000, May 29, 2015 Version. Geol. Surv. Japan, AIST. 